\title{
Religious Symbols in Public Schools as Teachable Controversies in Religious Education
}

\section{Christian MoE ${ }^{1}$}

$\approx$ This focus issue of CEPS Journal raises two topics usually treated separately, Religious Education and the use of religious symbols in public schools. Both involve the challenge of applying liberal democratic principles of secularism and pluralism in a school setting and refract policies on religion under conditions of globalisation, modernisation and migration. I take this situation as a teachable moment and argue that it illustrates the potential of a particular kind of Religious Education, based on the scientific Study of Religion, for making sense of current debates in Europe, including the debate on religious education itself. However, this requires maintaining a spirit of free, unbiased comparative enquiry that may clash with political attempts to instrumentalise the subject as a means of integrating minority students into a value system.

Keywords: religious education, religious symbols, public schools, secularism 


\section{Religiozni simboli $v$ javnih šolah kot poučne kontroverze $\mathrm{v}$ religijskem izobraževanju}

Christian Moe

$\approx$ Tematska številka revije CEPS izpostavlja dve temi, ki se običajno obravnavata ločeno - pouk o religijah in uporaba religijskih simbolov v javni šoli. Obe zaznamuje izziv apliciranja liberalnodemokratičnih načel sekularizma in pluralizma v šolskem okolju, skozi obe se tudi lomijo politike glede religije $\mathrm{v}$ razmerah globalizacije, modernizacije in migracij. Takšne razmere predstavim kot priložnost za poučevanje in argumentiram, da ilustrira potencial specifičnega, na religiologiji utemeljenega predmeta o religijah, za osmišljanje trenutnih razprav v Evropi, vključno z razpravami o pouku o religijah. To pa zahteva ohranjanje duha svobodnega, nepristranskega primerjalnega raziskovanja, ki lahko trči ob politične poskuse instrumentalizacije predmeta kot sredstva integracije učencev iz manjšinskih skupnosti v sistem vrednot.

Ključne besede: religijsko izobraževanje, religiozni simboli, javne šole, sekularizem 


\section{Introduction}

This special issue of CEPS Journal raises two topics, Religious Education (RE) and religious symbols in public schools, which are usually treated separately, by different disciplines - respectively, those concerned with religion and teaching, and those concerned with law and public policy. Still, the two topics are linked in at least two ways.

First, both are concerned with the challenge of applying liberal democratic principles of secularism and pluralism in the public institutions of societies increasingly characterised by a plurality of religions and world-views. The school is a microcosm of the broader problems of multicultural coexistence and a subject of political contention. School policy on these issues is thus a helpful prism through which we can see refracted current European policies on religion and discern a spectrum of ideological positions. ${ }^{2}$

Second, both issues have taken on increasing salience in Europe in recent decades due to the perceived role of religion in problems with integrating immigrant minorities; the 'securitisation' of religion, especially Islam; and the rise of political movements that privilege native identities and reject liberal principles in a defensive reaction to globalisation, modernisation, and migration. ${ }^{3}$ A perceived need to integrate new (especially Muslim) minorities into a national culture of shared values is seen in the turn to 'civic integration' of immigrants since the 1990s, not only in residence/citizenship requirements but also in public schools, including RE (e.g., Fernández \& Jensen, 2017). This is to be expected, as public schools are society's main institution of secondary socialisation and cultural reproduction, and religion is still (despite secularisation) widely seen either as a 'social glue' or as a source of social discord that must be carefully controlled. European institutions have thus become increasingly concerned that intercultural education, including RE, should foster tolerance and other liberal values to promote social cohesion and prevent religious conflict (Committee of Ministers, 2008; Faas, Hajisoteriou, \& Angelides, 2014; OSCE/ ODIHR, 2007; PACE, 2005; REDCo, 2009). Meanwhile, national authorities across Europe have invoked integration into a national culture, conflated with Christian religious heritage and/or secular liberal values, to regulate various symbolic religious expressions in schools, and in a few cases to introduce new

2 E.g. the tentative distinction in Kuburić \& Moe (2006) between Slovenia’s 'liberal' approach to RE, Bosnia's, Croatia's and Serbia's 'multiculturalist' approach and the 'communalist' approach emerging in Macedonian debates.

3 While most far-right populist parties in Europe have not historically been particularly concerned with religion, they have become rhetorical defenders of Christendom through their opposition to immigrant Islam (Marzouki, McDonnell, \& Roy, 2016). 
teaching standards (Britain) or even new RE subjects (Norway). As discussed below, these measures have often been controversial, and some have ended in court, producing no less controversial judgements.

In this essay, I take this situation as a teachable moment and ask: How can educators respond pedagogically to these controversies as an opportunity to teach about religion? Relevant expert recommendations have focused on rights and process (Jackson, 2014, chapter 8 ) more than educational content. I outline study questions, discussion topics, and examples for conceptualising the public role of religious symbols, with suggestions for specific knowledge aims and thinking skills, and argue why the RE framework I consider is suited for making sense of these debates. ${ }^{4}$

The kind of RE considered here is a knowledge subject about religions which, like other school subjects, is taught to all pupils regardless of confession ('integrative' RE) and is rooted in an academic discipline, the scientific study of religion (Alberts, 2008, 2010; Jensen, 2008, 2010). A cross-disciplinary field that draws on the methods of history, philology, anthropology and sociology, the Study of Religion (SR) takes religion as empirically available social and cultural phenomena, studies these phenomena comparatively across cultures and over time, and develops concepts and theories to describe, analyse and account for them within a naturalistic framework, treating religious/supernatural truth claims as data to be explained, rather than as explanations. Like other academic disciplines, SR engages in a continuous process of self-critical reflection on method and theory, not least on such relevant problems in the present political context as the roles of insiders and outsiders (McCutcheon, 1999) and the representation of religious others (on textbooks, see, e.g. Andreassen \& Lewis, 2014).

Part of this process is an ongoing debate over what constitutes 'religion' itself as an object of study. Here, I take as my theoretical starting point a reflection on SR in the (university) classroom by Martin S. Jaffee, who begins by rejecting two influential understandings (religion as psycho-social 'experience' or phenomenological 'essence') in favour of a cultural-systems perspective in which religion is understood in a hermeneutic circle between theory and observation. Jaffee suggests that research-based teaching of comparative religion offers 'a certain sharpening of perception or education of taste', enabling students to grasp the role of religion in historical cultures and individual lives (Jaffee, 1999, p. 279). While I think SR offers a bit more than this, an educated taste is in itself a fine aim of a liberal education, and it could in time lead to more well-informed public debate and policy on religion than we find in the cases discussed below.

4 This is not to suggest, however, that understanding current events should be the primary purpose of, or justification for, RE. 
In the first section, I outline salient features of the controversies, focusing on prominent cases in European religious-freedom law as condensed expressions of public policy and debate: Norway's RE subject (the Folgerø case) and Italy's classroom crucifixes (the Lautsi case) in conjunction with several headscarf cases. I argue that there is a paradox in the authorities' handling of these cases that reveals deficiencies in the public understanding of religion and religious symbols. Therefore, I go on to highlight key theoretical concerns, analytical categories and findings from SR, to outline how SR-based RE can engage with the religious-symbols debate. In the concluding discussion, I consider how the increasing concern with integration in multi-religious societies represents an opportunity to implement integrative SR-based RE, but also a challenge to the vision of a subject exploring world-views rather than imparting them.

\section{$\mathrm{RE}$ and religious symbols: controversies and contradictions}

Diverse political dynamics favour RE that seeks to integrate pupils into a national identity by inculcating shared values, based on problematic equations between dominant religious traditions and national communities. Here I briefly consider the case of the compulsory integrative RE subject introduced in Norway in the 1990 (see also Andreassen, this focus issue).

In Norway, a state with an established church since 1537 (disestablished in 2012), elementary-school RE had been a mandatory 'Christianity' subject for members of the state Lutheran Church; since the 1970s, other children could take an alternative 'Worldviews and Ethics' class. In the 1990s school reforms, both options were replaced by a new mandatory, integrative subject on 'Christianity, Religions and Worldviews'. The new subject was not intended to preach one faith, but to teach about different religions through a common pedagogy, though with a quantitative focus on the majority religion. In effect, it represented a 'halfway house' between Christian religious instruction and a multireligious RE subject (Thomassen, 2006, p. 259).

The legislative record ${ }^{5}$ shows that the new religious diversity and the integration of immigrants were central concerns motivating the new RE policy, which must be understood in terms of the ingrained political desire to use the public school system as a tool for creating societal cohesion and national solidarity' (Thomassen, 2006, p. 258), led by the Labour Party, which was secular but

5 The official study (Pettersen, 1995), the government's White Paper (St. meld. nr. 14 [1995-96] Om kristendomskunnskap med religions- og livssynsorientering) and the parliamentary committee report (Innst. S. nr. 103 [1995-96]). 
comfortable wielding the instrument of state religion. It was argued that successful integration depended on minorities mastering the 'cultural code' of Norwegian society by learning about its 'deep current' of Christianity. Pupils would also learn more about five minority worldviews (Judaism, Islam, Buddhism, Hinduism, and Humanism), but as 'other' and apparently less important religions.

Ironically, this policy succeeded in fostering dialogue and unity across religious lines by bringing minority religions together on a common platform for the first time - to protest the new RE subject. ${ }^{6}$ A group of Humanist parents sued the government all the way to the European Court of Human Rights (ECtHR). It should be kept in mind that the ECtHR, when interpreting the right to freedom of opinion and religion and the scope for legitimate restrictions on that right (Nowak \& Vospernik, 2004), has applied a form of power analysis to proselytism and indoctrination. While proselytising for one's religion is a protected exercise of religious freedom, it violates the religious freedom of others when the proselytiser holds authority over the proselytised. ${ }^{7}$ Public schools must, therefore, allow exemptions from subjects that are 'indoctrinating', in order to prevent the state from infringing on the right of parents to an education for their children in accordance with their convictions. However, schools may teach compulsory subjects, even if they clash with parents' convictions, as long as the subject is taught in an 'objective, critical and pluralistic way'. ${ }^{8}$ In Folgerø v. Norway, the court by a 9-8 majority found that Norway had violated the parental right (ECtHR, 2007). The judgment turned on the restrictive exemption regime for the subject, its residual elements of Christian religious practice, and a legal framework that required schools to assist parents in the Christian upbringing of their children.

The subject has since been revised several times, the law changed, and the Church separated from the state. The subject has continued to evolve from its Christian-instruction origins, with carefully vetted contents, growing attention from SR scholars (von der Lippe \& Undheim, 2017), and elements of a thematic approach, despite the current right-wing government's policy to devote more than half the subject to Christianity. Its troubled history, however, offers a cautionary tale about using $\mathrm{RE}$ as a tool of integration into 'national values'.

6 The Council for Religious and Life Stance Communities in Norway was formed as an umbrella organisation for interfaith cooperation in 1996, in connection with protests against the new RE subject. As of 2019 it counts 15 member communities and works on a range of issues (https://www. trooglivssyn.no/english/).

7 Larissis v. Greece (1998), contrast Kokkinakis v. Greece (1993). For discussion see Nowak and Vospernik (2004, pp. 160-161).

8 The parental right is set out in the first Optional Protocol to the ECHR, art. 2; the 'objective, critical and pluralistic' test was set out in a Danish case on sex education in 1976, and has recently been applied to religious education (ECtHR, 2007, 2011). 
Controversies over religious symbols in public schools in Europe, too, have escalated from headmasters' offices through governments all the way to the ECtHR. They have mainly concerned whether Christian crucifixes or crosses may be displayed in classrooms and whether Muslim teachers or pupils may wear various forms of covering (hijab) including headscarves. Because states are required to make non-discriminatory laws, however, attempts to regulate these two religions and symbols tend to result in wider impacts, as with the French law against 'ostentatious' religious attire (Bowen, 2007) that clearly targets hijabs but also affects Jewish pupils with kippas, Sikhs with turbans and Christians with large crosses. Related issues that can only be mentioned in passing here include collective prayers, prayer spaces, exemptions from swimming lessons, and shaking hands with the other sex. As we will see, these are somewhat different kinds of symbols, subject to different ritual rules that are differently gendered, and used by different kinds of actors.

When conflicts escalate beyond the individual school, they must be resolved according to the abstract, universal, neutrally applicable principles of the secular state. This reduces the scope for individual adaptations, flexibility, and compromise that exists in face-to-face negotiations in the school setting. The 'thick' meanings of religious symbols and behaviour are translated into the 'thin' language of the secular legal order, notably into the vocabulary of human rights. Much is lost in translation.

Based on the same kind of power analysis used for 'indoctrinating' subjects (see above), one might expect the ECtHR to uphold pupils' religious freedom both to wear headscarves and to have classrooms free from crucifixes. Crucifixes are, after all, displayed in classrooms by state institutions holding authority over children. The hijab, in contrast, is worn by individual girls and women, and disputes arise when the state seeks to restrict it. The court might reasonably see a teacher with a headscarf as a more complex case, requiring a balanced consideration of her two aspects as both an individual believer and a state agent with authority over children. It might further highlight the intersection of gender discrimination and religious discrimination at play when the state excludes Muslim minority girls or women from schools for conforming to religious norms, impairing their right to education or work.

The ECtHR, however, has done the opposite. In Lautsi and others v. Italy (ECtHR, 2011), it ultimately upheld Italy's Fascist-era decrees mandating the display of crucifixes in public schools; in Dogru v. France (ECtHR, 2008), it upheld the expulsion of a schoolgirl for wearing a headscarf; and in Dahlab v. Switzerland (ECtHR, 2001), the case of a teacher prohibited from wearing a headscarf while teaching, it simply dismissed her application as unfounded. 
This paradox is mostly explained by the court's deference to state authorities in religious matters (states' 'margin of appreciation') and the difficulty of developing a consistent European jurisprudence on religion when states have markedly different traditions of secularism and state-church relations. However, to justify their decisions, both national and international authorities have also resorted to contrived interpretations of religious symbols.

In Lautsi, the Italian Administrative Court went to the astonishing lengths of arguing that the crucifix actually symbolised secularism (for a detailed critique, see Gedicks \& Annicchino, 2013). It held that the modern notions of tolerance and liberties were historically linked to a Christian emphasis on 'charity over faith' and 'rendering unto Caesar what is Caesar's. Though the link was non-obvious, like an underground stream, the court was able to identify such principles, even religious freedom, in the 'central core of Christian faith'. All religious convictions were inherently exclusive except one - Christianity 'as properly understood'. Besides national identity, the crucifix thus also symbolised 'liberty, equality, human rights and religious toleration, and [...] the secular nature of the State. It should be affirmed in order to transmit 'the refusal of any form of fundamentalism' to 'numerous pupils from outside the European Union' (probably meaning Muslims and stereotyping them as prone to 'fundamentalism'). Therefore, it would be 'something of a paradox' to exclude it from a public institution in the name of secularism (Administrative Court, quoted in ECtHR, 2011, para. 15). On appeal, the Supreme Administrative Court held that the crucifix symbolised 'the religious origin of' values which 'characterise Italian civilisation' (tolerance, rights, etc.) without detracting from their secular value, which could be affirmed by all. The crucifix could, therefore, fulfil 'a highly educational symbolic function, irrespective of the religion professed by the pupils' (Consiglio di Stato, quoted in ECtHR, 2011, para. 16).

The final ECtHR judgement considered the crucifix 'above all a religious symbol' and wisely avoided further interpretations, except to call it 'an essentially passive symbol' (ECtHR, 2011, para. 72). In the Dahlab case, however, the same court had argued that a headscarf could be a 'powerful external symbol' with a proselytising effect on young children (ECtHR, 2001). What made a crucifix on a classroom wall 'passive' and a headscarf on a teacher's head 'powerful'? The ECtHR sought to dismiss the contradiction by saying the facts of the two cases were entirely different (2011, para. 73), without explaining how the difference was relevant.

Observations of similar court cases on religion, and of the 'murky mixture' of arguments about religious symbols that inform judges' decisions, have led some to declare 'the impossibility of religious freedom' as a justiciable legal right (Sullivan, 2005, esp. pp. 5-8). 


\section{Teachable controversies}

Unlike Sullivan, I am optimistic that religious freedom can be meaningfully protected by liberal democracies through knowledge-based state regulation of religious practice and identity. However, as conflicts in this area involve essentially contested concepts and 'thick doctrines', in modern plural societies they are better seen as tensions to manage and learn from than as problems to solve once and for all. ${ }^{9}$ They can serve as 'teachable controversies': $:^{10}$ studying and discussing such conflicts is a democratic exercise. While this can be done in Citizenship classes, an RE framework allows exploring the religious convictions behind the symbols as well as the classifications that guide policy (religious/ secular, sacred/profane). This can be a learning experience both for pupils and for the educators who are first in line to manage the issues when they arise. In the following, I outline discussion topics reflecting the strengths of SR-based $\mathrm{RE}$ as a laboratory for analysing religious-symbol issues.

\section{Interpreting ambiguity, assessing authority}

SR training helps resist the trap of reducing symbols to any one authoritative meaning. Religious symbols tend to be highly multivocal or polysemous (Turner, 1967, p. 50): they can stand for multiple, seemingly contradictory meanings, which can also emerge and change over time. For example, there is a traditional Islamic legal discourse that explains hijab in terms of women's duty to avoid arousing male passions and causing seduction/social strife (fitna), and a modern Muslim women's discourse of the hijab as an individual right, a personal choice, an expression of their Muslim identity and a protection against harassment; today, these discourses co-exist uneasily (see, e.g., Mir-Hosseini, 2007). Even the notion that the crucifix could stand for secularism should not be dismissed out of hand. However, some interpretations are more plausible than others, for example, in terms of being supported by contextual evidence.

Religious symbols are not interpreted in a vacuum, but with reference to context and to the relevant interpretive communities (Scharffs, 2012), which in turn adhere to established interpretive authorities and meanings. All of these,

9 Rules are needed, of course, but on this view, rules should not be fixed in national law; rather, they should be made on lower administrative levels; be subject to review in the light of experience; empower headmasters to experiment with compromises; and provide for processes of negotiation. An example of the latter is the Bavarian compromise that crucifixes may be displayed, but that parents can contest the display locally (ECtHR, 2011, para. 28, p. 13).

10 'Teach the controversy' is a slogan notoriously used by creationists and global-warming deniers, to cast doubt on settled science. It nevertheless seems an appropriate motto for conflicts over religious symbols, where not only policy choices but the symbolic meanings themselves are bound up with contested values. 
however, may be plural and divergent in a given case. It is, therefore, essential to understand different traditions' authority structures and interpretive methods. There are practical limits to how far this diversity can be covered in RE, but it should be conveyed, for example. that Islam has no pope or central teaching authority; it has scholars, aligned with various traditional schools of thought, who derive religious norms from a widely agreed set of sources and methods but differ over many details and the importance placed on them. The student of Islam therefore quickly learns to ask 'Whose Islam?' and not to take the opinion of any one Muslim authority as dispositive for all Muslims, for example, as to whether a particular form of covering (niqab, burqa) is a religious requirement.

\section{Comparison and classification: religious symbols}

SR-based RE helps place symbols and policies toward them into a comparative perspective. Comparison, as well as the companion issue of classification, is a long-standing concern in SR, from the ethnographic miscellanies of early anthropologists through the phenomenology of religion to recent methodological reflections that have been sharpened by post-modernist and political critiques (Carter, 2004; Patton \& Ray, 2000; Smith, 1982). RE often features units devoted to particular phenomena across religious traditions, such as pilgrimage, holy books, mystical experience or dietary rules. This thematic approach trains students to consider similar features in different religions and world-views, while the systematic approach to each religious tradition as a unit provides a check on the aptness of such comparisons.

Exploring hijabs and crosses in the classroom, one might start from pupils' own experience of how people express their identities through clothing and fashion: what one can tell from their attire, haircuts, and accessories. ${ }^{11}$ One might go on to discuss other religious headgear (nun's habits, kippas, turbans), in what contexts religious people cover and uncover their heads, what the symbolism is, and whether there are also secular public rituals and symbols of a similar nature, for example, in the army or courtroom. (For a classic discussion along these lines, see Hallpike, 1969/1979.)

Such comparisons lead to analysis in terms of critical categories like 'the sacred' or 'gender', revealing differences between the symbols themselves that may or may not justify different treatment. For instance, the cross (and in some churches, the crucifix) is instantly recognisable not just as a Christian symbol, but as the symbol emblematic of the religion as a whole, much like a flag stands for the nation - a 'summarizing symbol' (Ortner, 1973/1979). Crucifixes and crosses are considered sacred items, used for ritual purposes and centrally

11 Preferably without putting minority students in the class on the spot as exemplars of their religion. 
displayed in churches. However, the cross also features in secular contexts (e.g., medical signs). It may be casually worn (by both sexes) in any situation both as an expression of piety and as a profane ornament. The headscarf, in contrast, is a piece of cloth with no intrinsic sanctity. It is worn only by women, and Muslims widely consider it a religious duty for women to be covered in the company of men who are not closely related to them. Such a gendered expression of sexual modesty grounded in religious morality is also at stake in other public-school issues (swimming, handshakes). Since the 'Islamic awakening' of the 1970s, the hijab has taken on a range of meanings, including political ones, and the hijab-clad woman has become a symbol of Islam. Conversely, the kippa is worn as a religious duty by male Jews, and the turban mostly but not exclusively by male Sikhs (whose religious duty centres on the unshorn hair it covers). All of these symbols can express a person's piety and devotion, as well as their affiliation to a community set apart from others.

After this analysis, one can return to the issue of school dress codes with a better idea of the different stated and unstated reasons people might have for displaying religious symbols and reacting to their regulation. Considering sexual modesty, pupils might reflect on how they would feel if a school dress code required them to expose themselves indecently by Western cultural standards; considering identity, they might consider whether banning such items might cause more young people to wear them as a 'punk' sign of protest.

\section{Comparison and classification: Regulating religion}

Another line of comparison, requiring more specialised historical background knowledge, is how state authority in other times and places has treated the religious symbols of others, and how these policies have shaped public space. What are the similarities and differences between hijab laws in Iran, Turkey, and France? How do they compare with the 'hat laws' introduced in Turkey and Iran in the early 2oth century? More generally, can we find points of comparison between today's secular toleration policies and very different regimes, like the Roman state's toleration of cults that venerated the Emperor, or the late Ottoman millet system? How do laïcist public dress codes that compel minorities to hide religious difference, compare with those in medieval Christendom and Islam that compelled religious minorities to mark their difference visibly (e.g., 'Jewish badges')?

Debates on the regulation of religious symbols often turn on broad classifications. As seen in the Lautsi case, it is often asserted that, for example, a crucifix is acceptable in classrooms because it should be understood as a cultural symbol, conventional in the majority culture, and not as an object of religious 
veneration; therefore, the argument goes, it does not infringe on the separation between state and religion. A variety of similar, strategically inflected arguments may be brought to bear on other people's symbols: The Muslim headscarf can variously be portrayed as religious (and thus unacceptable in secular schools); as a cultural tradition (hence not protected by religious freedom), or as primarily a political statement (more often to paint it as a dangerous challenge to the Western constitutional order than to afford it protection under freedom of expression).

To assess these arguments, it is helpful to recall that symbols have multiple meanings, so they can belong to several spheres at once. Religion has often served as a source of political legitimacy as well as a medium for propagating political messages and a collective identity that can be mobilised for political ends. It is also helpful to recall the SR understanding of religion as a social and cultural phenomenon: there is no religious symbol that is not cultural. The converse is not true: we can and do classify cultural elements and social practices as religious or not (otherwise SR could not exist). Indeed, the differentiation of religion as a social subsystem is a key element of modernisation (e.g., Beyer, 1994). However, if the social dynamics of religion can be studied and accounted for by similar methods and theories as profane social phenomena (e.g., fashion, ethno-nationalism, etc.), distinctions between 'pure' religion and culture/society/politics may be seen less as analytical tools than as social constructions to be analysed.

\section{Critical reading and thinking skills}

By advocating RE as training in critical thinking, I do not mean to advocate a pedagogical approach that focuses on propositional reasoning about ethics or religious philosophy from or through religion. Instead, I think primarily of teaching pupils to apply source criticism and to identify and mitigate cognitive biases and fallacious modes of reasoning when learning about religion.

As an illustration, consider the courts' reasoning in Lautsi. To identify Christianity with religious freedom and tolerance, the Italian court had to exclude much historical evidence ad hoc from the 'core' of Christianity as 'properly understood', thus committing the 'no true Scotsman' fallacy. The court's exceptionalist claim for Christianity as uniquely non-exclusionary makes highly selective use of religious texts ('charity above faith', 'render unto Caesar'). It also exhibits the fallacy of religious congruence (Chaves, 2010) or scriptural determinism (Appiah, 2018): the empirically ill-supported assumption that believers' behaviour will accord with their beliefs and texts. In short, the court identified its in-group (Italian Christian civilisation) with uniquely positive values and 
virtues by resorting to special pleading. Training in SR sensitises students to such special pleading about religion.

This is in part because SR-based RE adds a dimension to the source criticism that is already taught, for example, in History classes. SR is also concerned with what people have believed happened in the far past and what it has meant to them, not only with what actually happened. That is, it is concerned with the second-order hermeneutics of understanding religious interpretations of the religious sources, not only with interpreting those sources themselves. Moreover, due to its comparative bent, SR has greatly concerned itself with peoples distant in space, culture and power from the researcher, and has had to reflect on its role and biases in representing others (e.g., in response to Said, 1978/1995).

\section{Nuancing the secular}

SR offers analytical and historical insight into the religious and the secular, secularisation, and secularism. With regard to secularisation, pupils can learn that while sociologists had long expected religiosity to decline in the modern world, developments in the last few decades have called secularisation theory into question (e.g., Berger, 1999), and that more careful distinctions have lately been drawn, for example, between secularisation as decline, differentiation, and privatisation (Casanova, 1994), or between religiosity as believing or belonging (Davie, 1994). In this perspective, one may discuss whether the hijab-as-women's-right and crucifix-as-secularism arguments represent a remarkable, ironic secularisation, or a re-assertion of religion as collective and public identity.

With regard to secularism, pupils can learn to distinguish between secularism as the institutional neutrality of the state towards the religions of its citizens, and secularism as laïcism, a thicker ideology requiring the religious neutrality of citizens in their relations with the state (as well as vigilant state control of religious expression). They should be aware that notionally secular European states differ widely in their approaches to religion, from laïcism to state religions (established churches) with accommodations for other religions, and they should be able to apply this knowledge, for example, to the widely differing approaches of the UK and France to religious dress in school.

Pupils might also learn about a third option mediating between state religion and state irreligion, namely 'civil religion', a 'sui generis hybrid of religion and national communality' that is 'intricately intertwined with nationalism' (Hvithamar, Warburg, \& Jacobsen, 2009, p. 5). First suggested by Rousseau as a 'purely civil profession of faith' that governments should impose to make loyal, law-abiding citizens (Rousseau, 1999, pp. 166-168), a civil religion has 
been identified in American public speeches and ceremonies (Bellah, 1967), and in a variety of other contexts. When public authorities use religion to foster national cohesion and tolerance - whether in the form of common symbols and rituals or in the form of a specific kind of RE - the question arises whether they are promoting a form of civil religion rather than a non-confessional education.

\section{Discussion}

Educators can respond to controversy over religious symbols in schools by 'teaching the controversy' through RE, drawing on the resources of the scientific Study of Religion as outlined above with reference to the Lautsi and headscarf cases. The concern with national cohesion that is driving the controversies represents both an opportunity and a challenge for SR-based RE.

The opportunity is a clear imperative for 'integrative' RE about different religions taught to all pupils the same way. Religion is widely conflated with morality, and migrant identities with religion, which makes RE prone to becoming the designated 'values-and-integration subject'. Indeed, RE can be made to integrate students into 'national values', whether understood as a cultural identity and its religious tradition(s), a set of democratic-secular values, or a mix of both. This is a temptation for policy-makers both on the right and the left. The challenge, then, is that RE may be geared more to 'integration' than education.

The politics of immigration after the 2015 'surge', the securitisation of immigrants' religion and the rise of populist nationalism will likely continue to reinforce pressures both to police the display of minority religious symbols and to use RE to promote 'integration' through 'national values' and prevent 'extremism'. This will not necessarily take the blatant form of a nativist demand that immigrants assimilate to the majority religion. Instead, it may take the form of a subject heavily geared towards teaching, for example, gender equality or other civic values that immigrants are supposed to lack. It might not result in a wholesale revision of RE, as in 1990s Norway, but instead come as piecemeal programmes and requirements, such as the teaching standards introduced in the UK in the early 2010 s that require teachers to promote 'Fundamental British Values' (see criticism in Richardson, 2015; Farrell, 2016), or the increased stress on Christianity in Denmark (Fernández \& Jensen, 2017).

I suggest, however, that an overemphasis on shared values and identity would be detrimental to the kind of RE that I have discussed here. First, given finite time and resources, a strong emphasis on values will come at the expense of learning about other religions. This trade-off is too easily ignored due to the 
widespread failure to recognise religion as a field of knowledge (as opposed to moral sentiment, existential wonder, and subjective experience). Second, an overemphasis on imparting values rather than exposing students to a range of values and ideas would detract from the subject's mission of fostering critical enquiry. This holds whether the values in question are liberal, national, or confessional.

Third, to use RE to integrate pupils into a shared, approved worldview is to miss the unique qualities SR-based RE can bring to education. SR has evolved as a comparative discipline that ultimately takes different human worlds of meaning as its subject of comparison. Like few other academic disciplines, SR has the knack of 'making the familiar strange and the strange familiar' (Muesse, 1999; cf. Smith, 2004, p. 389). By doing so, it offers students a chance to disintegrate themselves from their cultural matrix and to look at their own society and culture from new vantage points before re-integrating these insights within an academic framework. The above discussion offers several examples of such perspective shifts.

'By reflecting upon the most comprehensive constructions of the world's order, one cannot escape an impression of the historically contingent character of all worlds, including one's own', Jaffee notes in the paper cited in the introduction. Accordingly, he sees his university classroom as 'a place to model a theoretically articulate pluralism regarding the cultural definition of Truth', including 'the moral consequences and rhetorical dimensions of the very theoretical positions which enable our perspective' (Jaffee, 1999, p. 280).

Within the constraints of a school subject, RE can perform a similar service for children. If it is too concerned with fostering shared identity and values, however, it not only risks encroaching on religious freedom, as in the Norwegian case, and further alienating the minorities it is meant to integrate. It also misses its chance to give majority pupils insight into other people's worlds and an outside perspective on their own.

\section{References}

Alberts, W. (2008). Didactics of the study of religions. Numen, 55(2-3), 300-334.

Alberts, W. (2010). The academic study of religions and integrative religious education in Europe. British Journal of Religious Education, 32(3), 275-29o. Retrieved from https://doi.org/10.1080/014162 00.2010 .498621

Andreassen, B.-O., \& Lewis, J. R. (Eds.). (2014). Textbook gods: Genre, text, and teaching religious studies. Sheffield, UK \& Bristol, CT: Equinox.

Appiah, A. (2018). The lies that bind: Rethinking identity, creed, country, color, class, culture (1st ed.). New York, NY: Liveright Publishing Corporation. 
Bellah, R. N. (1967). Civil religion in America. Daedalus, 96(1), 1-21.

Berger, P. L. (1999). The desecularization of the world: A global overview. In Berger (Ed.), The desecularization of the world: Resurgent religion and world politics (pp. 1-18). Washington, D.C: Ethics and Public Policy Center \& William B. Eerdmans.

Beyer, P. (1994). Religion and globalization. London, UK \& Thousand Oaks, CA: Sage Publications. Bowen, J. R. (2007). Why the French don't like headscarves: Islam, the state, and public space.

Princeton, NJ: Princeton University Press.

Carter, J. (Ed.). (2004). Special issue: Comparison in the history of religions. Method and Theory in the Study of Religion, 16(1), 3-101.

Casanova, J. (1994). Public religions in the modern world. Chicago, IL: University of Chicago Press. Chaves, M. (2010). Rain dances in the dry season: Overcoming the religious congruence fallacy (SSSR presidential address). Journal for the Scientific Study of Religion, 49(1), 1-14. Retrieved from https://doi.org/10.1111/j.1468-5906.2009.01489.X

Committee of Ministers. (2008). Recommendation CM/Rec(2008)12 of the Committee of Ministers to Member states on the dimension of religions and non-religious convictions within intercultural education. Council of Europe.

Davie, G. (1994). Religion in Britain since 1945: Believing without belonging. Oxford, UK: Blackwell Publishers.

ECtHR (European Court of Human Rights). (2001). Dahlab v. Switzerland: decision on admissibility (Application No. 42393/98). Strasbourg: European Court of Human Rights.

ECtHR. (2007). Folgerø and others v. Norway: Grand Chamber judgment (Application No. 15472/02). Strasbourg: European Court of Human Rights.

ECtHR. (2008). Dogru v. France: Judgment (Application No. 27058/05). Strasbourg: European Court of Human Rights.

ECtHR. (2011). Lautsi and others v. Italy: Grand Chamber judgment (Application No. 30814/o6).

Strasbourg: European Court of Human Rights.

Faas, D., Hajisoteriou, C., \& Angelides, P. (2014). Intercultural education in Europe: Policies, practices and trends. British Educational Research Journal, 4o(2), 300-318. Retrieved from https://doi. org/10.1002/berj.3080

Farrell, F. (2016). 'Why all of a sudden do we need to teach fundamental British values?' A critical investigation of religious education student teacher positioning within a policy discourse of discipline and control. Journal of Education for Teaching, 42(3), 280-297. Retrieved from https://doi. org/10.1080/02607476.2016.1184460

Fernández, C., \& Jensen, K. K. (2017). The civic integrationist turn in Danish and Swedish school politics. Comparative Migration Studies, 5(1). Retrieved from https://doi.org/10.1186/s40878-017oo $49-\mathrm{Z}$

Gedicks, F. M., \& Annicchino, P. (2013). Cross, crucifix, culture: An approach to the constitutional meaning of confessional symbols (Working Paper No. RSCAS 2013/88). European University Institute. Hallpike, C. R. (1979[1969]). Social hair. In W. A. Lessa \& E. Z. Vogt (Eds.), Reader in comparative 
religion: An anthropological approach (4th ed., pp. 99-105). New York, NY: Harper Collins Publishers. Hvithamar, A., Warburg, M., \& Jacobsen, B. A. (Eds.). (2009). Holy nations and global identities: Civil religion, nationalism, and globalisation. Leiden \& Boston, MA: Brill.

Jackson, R. (Ed.). (2014). Signposts: Policy and practice for teaching about religions and non-religious world views in intercultural education. Strasbourg: Council of Europe.

Jaffee, M. S. (1999). Fessing up in theory: On professing and confessing in the Religious Studies classroom. In R. T. McCutcheon (Ed.), The insider/outsider problem in the study of religion: A reader (pp. 274-286). London, UK \& New York, NY: Cassell.

Jensen, T. (2008). RS based RE in public schools: A must for a secular state. Numen, 55(2), 123-150. Retrieved from https://doi.org/10.1163/156852708X283023

Jensen, T. (2010). Integrative religious education in Europe: A study-of-religions approach. Religion, 40(1), 63-65. Retrieved from https://doi.org/10.1016/j.religion.2009.04.001

Kuburić, Z., \& Moe, C. (Eds.). (2006). Religion and pluralism in education: Comparative approaches in the Western Balkans. Novi Sad: CEIR.

Marzouki, N., McDonnell, D., \& Roy, O. (Eds.). (2016). Saving the people: How populists hijack religion. London, UK: Hurst \& Company.

McCutcheon, R. T. (Ed.). (1999). The insider/outsider problem in the study of religion: A reader. London, UK \& New York, NY: Cassell.

Mir-Hosseini, Z. (2007). The politics and hermeneutics of hijab in Iran: From confinement to choice. Muslim World Journal of Human Rights, 4(1). https://doi.org/10.2202/1554-4419.1114

Muesse, M. W. (1999). Religious studies and "Heaven's Gate": Making the strange familiar and the familiar strange. In R. T. McCutcheon (Ed.), The insider/outsider problem in the study of religion: A reader (pp. 390-394). London, UK \& New York, NY: Cassell.

Nowak, M., \& Vospernik, T. (2004). Permissible restrictions on the freedom of religion or belief. In T. Lindholm, W. C. Durham Jr., \& B. G. Tahzib-Lie (Eds.), Facilitating freedom of religion or belief: A deskbook (pp. 147-172). Leiden: Brill.

Ortner, S. B. (1979[1973]). On key symbols. In W. A. Lessa \& E. Z. Vogt (Eds.), Reader in comparative religion: An anthropological approach (4th ed., pp. 92-98). New York, NY: Harper Collins Publishers. OSCE/ODIHR (Organisation for Security and Co-operation in Europe Office for Democratic Institutions and Human Rights). (2007). Toledo guiding principles on teaching about religions and beliefs in public schools: Prepared by the ODIHR advisory council of experts on freedom of religion or belief. Warsaw: ODIHR.

PACE (Parliamentary Assembly of the Council of Europe). (2005). Recommendation 1720 (2005).

Education and religion. Retrieved from http://assembly.coe.int/nw/xml/XRef/Xref-XML2HTML-en. asp? fileid $=17373$

Patton, K. C., \& Ray, B. C. (Eds.). (200o). A magic still dwells: Comparative religion in the post-modern age. Berkeley, CA: University of California Press.

Pettersen, E. (1995). Identitet og dialog: kristendomskunnskap, livssynskunnskap og religionsundervisning [Identity and dialogue: Knowledge about Christianity, knowledge about 
worldviews and religious education]. Oslo: Statens Forvaltningstjeneste.

REDCo. (2009). Religion in education: Contributions to dialogue: Policy recommendations of the REDCo research project. Retrieved from https://patternsofgoverningreligion.weebly.com/ uploads/2/7/o/3/27037565/redco_policy_recommendations_eng.pdf Richardson, R. (2015). British values and British identity: Muddles, mixtures, and ways ahead. London Review of Education, 13(2), 37-48. Retrieved from https://doi.org/10.18546/LRE.13.2.04 Rousseau, J.-J. (1999). Discourse on political economy and the social contract. Oxford, UK \& New York, NY: Oxford University Press.

Said, E. W. (1995[1978]). Orientalism: Western conceptions of the Orient (reprinted with a new afterword). London, UK: Penguin Books.

Scharffs, B. G. (2012). The role of judges in determining the meaning of religious symbols. In J. Temperman (Ed.), The Lautsi papers: Multidisciplinary reflections on religious symbols in the public school classroom (pp. 35-58). Leiden \& Boston, MA: Martinus Nijhoff Publishers.

Smith, J. Z. (1982). In comparison a magic dwells. In J. Z. Smith (Ed.), Imagining religion: From Babylon to Jonestown (pp. 19-35). Chicago, IL: University of Chicago Press.

Smith, J. Z. (2004). Relating religion: Essays in the study of religion. Chicago, IL: University of Chicago Press.

Sullivan, W. F. (2005). The impossibility of religious freedom. Princeton, NJ: Princeton University Press.

Thomassen, E. (2006). Religious education in a pluralistic society: Experiences from Norway. In M.

Pye, E. Franke, A. T. Wasim, \& A. Ma’sud (Eds.), Religious harmony: Problems, practice, and education (pp. 257-266). Berlin \& New York, NY: Walter de Gruyter.

Turner, V. (1967). The forest of symbols: Aspects of Ndembu ritual. Ithaca, NY: Cornell Univ. Press. von der Lippe, M., \& Undheim, S. (Eds.). (2017). Religion i skolen [Religion in school]. Oslo: Universitetsforlaget.

\section{Biographical note}

Christian MoE is an independent researcher in the History of Religions based in Ljubljana, Slovenia. His research interests include contemporary Islam, religious reform and human rights. 